\title{
SLAUGYTOJŲ ŽINIOS APIE NAUJAGIMIŲ GAIVINIMĄ, ATSIŽVELGIANT İ IŠSIMOKSLINIMĄ
}

\author{
Silva Kostylioviené ${ }^{1}$, Toma Mažeikaitė ${ }^{1}$, Monika Krauzaitė ${ }^{1}$, \\ Dovilè Grinkevičiūté丶 \\ ${ }^{1}$ Kauno kolegijos Medicinos fakulteto Slaugos katedra, \\ ${ }^{2}$ Lietuvos sveikatos mokslu universiteto Medicinos fakulteto Vaiku ligu klinika, \\ ${ }^{3}$ Lietuvos sveikatos mokslu universiteto Slaugos fakulteto Slaugos ir rüpybos katedra
}

Raktažodžiai: naujagimio gaivinimas, slaugytojų žinios, slaugytojų išsimokslinimas.

\section{Santrauka}

Pasaulio sveikatos organizacijos (PSO) duomenimis, pasaulyje per pirmaji gyvenimo mènesi 2018 metais mirè 2,5 mln., o kiekvieną dieną miršta apie 7000 naujagimių. Naujagimių mirties priežastys gali būti įvairios, tačiau dažniausiai mirštama nuo ịgimtų formavimosi ydų, infekcijų, perinatalinio laikotarpio, kvėpavimo sistemos, kraujotakos sistemų ligų, staigios kūdikio mirties sindromo (SKMS) ar gimdymo traumos. Naujagimio gaivinimo algoritmas skiriasi nuo suaugusiojo ar vaiko gaivinimo ne tik paspaudimų ir ịpūtimų santykiu, bet ir gaivinimo veiksmais bei jų seka. Atliktų tyrimų rezultatai rodo, kad slaugytojams vis dar trūksta žinių apie naujagimio gaivinimą. Nustatyta, kad apie 61,0 proc. naujagimių gaivinimo metu patiria įvairių komplikacijų, todèl labai svarbu, kad sveikatos priežiūros specialistai, teikiantys neatidèliotiną ir skubiają pagalbą, gerai žinotų naujagimio gaivinimo standartą ir gebètų kokybiškai atlikti naujagimio gaivinimą.

Tyrimo tikslas - išanalizuoti slaugytojų žinias apie naujagimių gaivinimą, atsižvelgiant ị išsimokslinimą. Taikytas kiekybinis tyrimo metodas, duomenys rinkti anoniminio anketavimo būdu. Apklausti 78 slaugytojai, teikiantys naujagimiams neatidèliotiną ir būtinajją pagalbą. Analizuojant rezultatus, nustatyta, kad didžioji dalis slaugytojų, turinčiu aukštesnijị ir aukštajj neuniversitetini išsimokslinimą, žinojo pirmujjų naujagimio gaivinimo veiksmų trukmę, ipūtimų skaičių per 30 sek., paspaudimų ir ịpūtimų santykị, vienkartinę epinefrino dozę. Tuo tarpu didžioji dalis turinčių aukštajį universitetinị išsimokslinimą, žinojo ịpūtimų skaičių per 30 sek., krūtinès ląstos paspaudimų metodą. Tik nedidele dalis slaugytojų, turinčių aukštajị universitetinị ir aukštaji neuniversitetinị išsimokslinimą, nežinojo tikslaus naujagimio paspaudimų ir ịpūtimų santykio, naujagimio gaivinimo metu švirkščiamo epinefrino dozès ir injekcijos vietos.

\section{Ivadas}

Jungtinių tautų organizacijos (JTO) duomenimis, pasaulyje kasdien gimsta apie 385000 kūdikių (140 milijonų per metus) [1]. Europos Sajungoje 2018 metais užregistruota 4,96 mln. gyvų gimusių naujagimių [2]. Per pastaruosius dešimt metų (2010-2019) Lietuvoje gimè 297,993 tūkstančiai gyvų gimusių naujagimių. 2019 metais gimè 27,393 tūkst. naujagimių. Lyginant su 2018 metų statistika, naujagimių skaičius sumažejo 756 [3]. Pasaulio sveikatos organizacijos (PSO) duomenimis, per pirmaji gyvenimo mènesį 2018 metais pasaulyje mire 2,4 mln. naujagimių, o kiekvieną dieną miršta apie 6700 naujagimių. Didžioji dalis naujagimių mirčių ịvyksta pirmają gyvenimo savaitę, o ypač daug naujagimių miršta per pirmąsias 24 valandas. $2019 \mathrm{~m}$. Lietuvoje daugiau kaip pusè visų mirusių kūdikių (59 kūdikiai arba 65,9 proc.) mirè neonataliniu (0-27 dienų amžiaus) laikotarpiu [4]. Naujagimių mirties priežastys ịvairios, tačiau dažniausiai mirštama nuo ịgimtų formavimosi ydų, infekcijų, perinatalinio laikotarpio ligų, kvejpavimo sistemos ligų, kraujotakos sistemų ligų, staigios kūdikio mirties sindromo (SKMS) ar gimdymo traumos [5].

Gimus naujagimiui, rekomenduojama ịvertinti jo būklę, remiantis trimis aspektais: išnešiotumu, raumenų tonusu ir kvejpavimo kokybe, kuriai priskiriamas ir verksmas. Jei visi aspektai ivertinami teigiamai, naujagimis paliekamas su motina oda prie odos kontaktui bei maitinti krūtimi [68]. Jei nors vienas aspektas ịvertintas neigiamai, naujagimi reikia perkelti ant šildomojo stalo ir atlikti išsamesnę būklès 
patikrą [6]. Rekomenduojama paeiliui atlikti šiuos veiksmus:

1) stabilizuoti: sušildyti ir užtikrinti pastovią temperatūrą, suteikti patogią padètį, pašalinti sekretą iš kvėpavimo takų, jeigu jis trikdo naujagimio kvèpavimą, nusausinti, stimuliuoti;

2) atlikti kvépavimo takų ventiliaciją ir deguonies terapiją;

3) atlikti krūtinès ląstos paspaudimus;

4) epinefrino injekciją ị virkštelès veną [6-8]. Epinefrino injekcijos dozè $0,1-0,3 \mathrm{ml} / \mathrm{kg}(1: 10000)$ [9].

Lietuvoje teisès aktais apibrèžta, kad naujagimis - tai vaikas, nuo gimimo iki 28 paru amžiaus, vaikui gimus prieš laiką - iki ménesio (28 parų) koreguoto amžiaus. Naujagimị gali tekti gaivinti ne tik gimdykloje. LR teisès aktuose nurodyta, kad naujagimis, išvykęs iš asmens sveikatos priežiūros ịstaigos, teikiančios akušerijos ir neonatologijos paslaugas, gali būti gaivinamas, taikant kūdikio gaivinimo algoritmą [10]. Sveikatos priežiūros specialistai, teikiantys neatidèliotiną ir skubiąją pagalbą, turètų gerai žinoti naujagimio gaivinimo standartą ir gebėti kokybiškai atlikti pradinį naujagimio gaivinimą. Nustatyta, kad apie 61,0 proc. naujagimiu gaivinimo metu patiria įvairių komplikacijų [11]. Komplikacijas gali išprovokuoti netgi pirmieji būtiniausieji veiksmai: šildymas, kvejpavimo taku valymas, atsiurbimas, stimuliavimas ir kt. [12]. Atliekant krūtinès ląstos paspaudimus netiksliai arba neturint ịūdžių, galima pažeisti naujagimio širdị, šonkaulius, krūtinkauli, plaučius ir kepenis [13]. Dėl kvejpavimo takų valymo ir atsiurbimo galima hipoksemija, bradikardija, hipotenzija, pneumotoraksas ir deguonies įsotinimo kraujyje sumažejimas [14]. Siekiant išvengti komplikacijų, gaivinimo komanda turi būti atidi, kvalifikuota ir patyrusi [13]. Tinkamai atliekamas naujagimio gaivinimas gali sumažinti šių komplikacijų skaičių.

Naujagimio gaivinimo algoritmas skiriasi nuo suaugusiojo ar vaiko gaivinimo ne tik paspaudimų ir ịpūtimų santykiu. Skirtingi pirmieji gaivinimo veiksmai bei gaivinimo veiksmų seka [6-9]. Nors naujagimio pradinio gaivinimo algoritme nèra ittraukti medikamentai, Lietuvos medicinos norma MN 28:2019 „Bendrosios praktikos slaugytojas“ suteikia teisę slaugytojui būtinosios medicinos pagalbos atveju savarankiškai skirti epinefriną [15]. LR sveikatos apsaugos ministro $2011 \mathrm{~m}$. rugpjūčio $31 \mathrm{~d}$. ịsakyme Nr. V-822 nurodoma, kad jei po 30 sekundžių trukusių ịpūtimų ir dar po 30 sekundžių ịpūtimų su paspaudimais ŠSD išlieka mažiau kaip 60 k./min., ị virkštelès veną ar trachèją srove sušvirkščiama epinefrino tirpalo [9]. Gaivinant naujagimį, kuris yra išvykęs iš stacionaro, galima taikyti vaiko gaivinimo algoritmą, tokiu atveju epinefrinas gali būti švirkščiamas ị periferinę veną ar kaulą [10].
Maždaug 10,0 proc. visų tik ką gimusių naujagimių reikia skatinti kvejpavimą, 3,0 proc. reikia teigiamo slègio ventiliacijos, o nedidelè dalis (1,0 proc.) reikalauja sudetingesniu intervencijų, tokių kaip intubacija, gaivinimas ir medikamentai [6], todèl labai svarbu laiku ir tinkamai atlikti pradini naujagimių gaivinimą, nes tai gali padèti išvengti naujagimių mirčių. Slaugytojai, kurie vis atnaujina ir plečia savo žinias, yra labai svarbūs naujagimio gaivinimo komandos nariai, nes slaugos specialistai užtikrina naujagimių saugumą ir gerą sveikatos būklę [16]. Tyrimų rezultatai atskleidžia, kad slaugytojams trūksta žinių apie naujagimio gaivinimą [16-18].

Tyrimo tikslas - išanalizuoti slaugytojų žinias apie naujagimių gaivinimą, atsižvelgiant i i išsimokslinimą.

\section{Tyrimo medžiaga ir metodai}

Tyrimas vyko nuo $2020 \mathrm{~m}$. spalio $16 \mathrm{~d}$. iki lapkričio $16 \mathrm{~d}$. $\mathrm{X}$ ligoninès Vaiku skubiosios pagalbos skyriuje (X VSPS), Y ligoninès Vaikų prièmimo, skubiosios pagalbos ir intensyviosios terapijos skyriuje (Y VPSPITS) bei X miesto GMP stotyje (X GMP). Duomenų rinkimo metodas - anoniminè anketinė apklausa. Tyrimo dalyviai - slaugytojai, teikiantys naujagimiams neatidèliotiną ir būtinają pagalbą.

Klausimyną sudare 24 klausimai, susiję su naujagimių būklès vertinimu, gaivinimo veiksmų atlikimu ir medikamentais, kurie naudojami naujagimio gaivinimo metu. Dometasi dalyvių patirtimi, klinikinëje praktikoje gaivinusių naujagimį.

Tyrimui vykdyti gautas tiriamujų įstaigų vadovų ir LSMU Bioetikos centro pritarimas Nr. BEC-KK(B)-03.

Dalyvauti tyrime buvo pakviesti visi slaugytojai ( $\mathrm{N}=133)$, dirbantys X VSPS, Y VPSPITS bei X GMP. Tinkami analizei gauti 78 klausimynai (atsako dažnis - 58,65 proc.).

Pagal išsimokslinimą, mažiau nei pusė $(46,2$ proc., $n=36)$ tyrime dalyvavusių slaugytojų turèjo aukštajį neuniversitetini išsimokslinimą; daugiau nei trečdalis $(38,5$ proc., $n=30)-$ aukštesniji, igytą medicinos mokykloje ir daugiau nei dešimtadalis (15,4 proc., $\mathrm{n}=12)$ - aukštajį universitetinị. Beveik pusè ( 45,6 proc., $n=35)$ respondentų nurodè turintys nuo 5 iki 15 metų darbo patirties; daugiau nei trečdalis $(34,6$ proc., $\mathrm{n}=27)$ - daugiau nei 15 metų ir apie penktadalis $(20,5$ proc., $\mathrm{n}=16$ ) - mažiau nei 5 metus darbo patirties.

Statistinei tyrimo duomenų analizei naudota SPSS 24.0 (angl. Statistical Package for the Social Sciences) programa. Analizuojant tyrimo duomenis, nagrinėjamų požymių pasiskirstymas imtyje buvo aprašomas procentiniu dažniu (proc.) ir skaitine charakteristika (n). Kokybinių požymių statistinis ryšys buvo tiriamas susietų lentelių metodu. Remiantis lentelių duomenimis, apskaičiuota chi kvadrato $\left(\chi^{2}\right)$ reikšmè, laisvès laipsnių skaičius (lls), rezultatai laikyti statistiškai patikimais, kai statistinio reikšmingumo koeficientas $p<0,05$. 


\section{Tyrimo rezultatai}

Analizuojant tyrimo rezultatus nustatyta, kad didžioji dalis respondentų $(82,1$ proc., $n=64$ ) klinikinèje praktikoje nebuvo gaivinę naujagimio, kiek daugiau nei dešimtadalis $(14,1$ proc., $\mathrm{n}=11)$ dalyvavo naujagimio gaivinime vieną kartą, labai mažai daliai respondentų teko dalyvauti naujagimio gaivinime 2-3 kartus $(2,6$ proc., $n=2)$ ir tik 1,3 proc. $(n=1)$ slaugytojų gaivino naujagimi daugiau nei 4 kartus. Truputị mažiau nei puse slaugytojų, dalyvavusių gaivinant naujagimi, nurode, kad gaivino 10-20 min. (35,7 proc., $\mathrm{n}=5)$, daugiau nei $20 \mathrm{~min}$. $(35,7$ proc., $n=5)$, mažiau nei 10 min. (28,6 proc., $n=4)$.

Pusė respondentų, kuriems klinikinèje praktikoje teko gaivinti naujagimi, teigè, kad jautėsi neramūs $(50,0$ proc., $n=7)$, apie dešimtadalis $(7,1$ proc., $n=1)$ - pasimetę, tačiau beveik pusè $(42,6$ proc., $n=6)$ jautèsi pasitikintys savimi ir ramūs.

Analizuojant rezultatus atsižvelgiant ị slaugytojų išsimokslinimą, nustatyta, kad visi (100 proc., $\mathrm{n}=30$ ) slaugytojai, turintys aukštesnijj išsimokslinimą, didžioji dalis turinčių aukštaji neuniversitetinį $(94,4$ proc., $n=34)$ ir aukštaji uni-

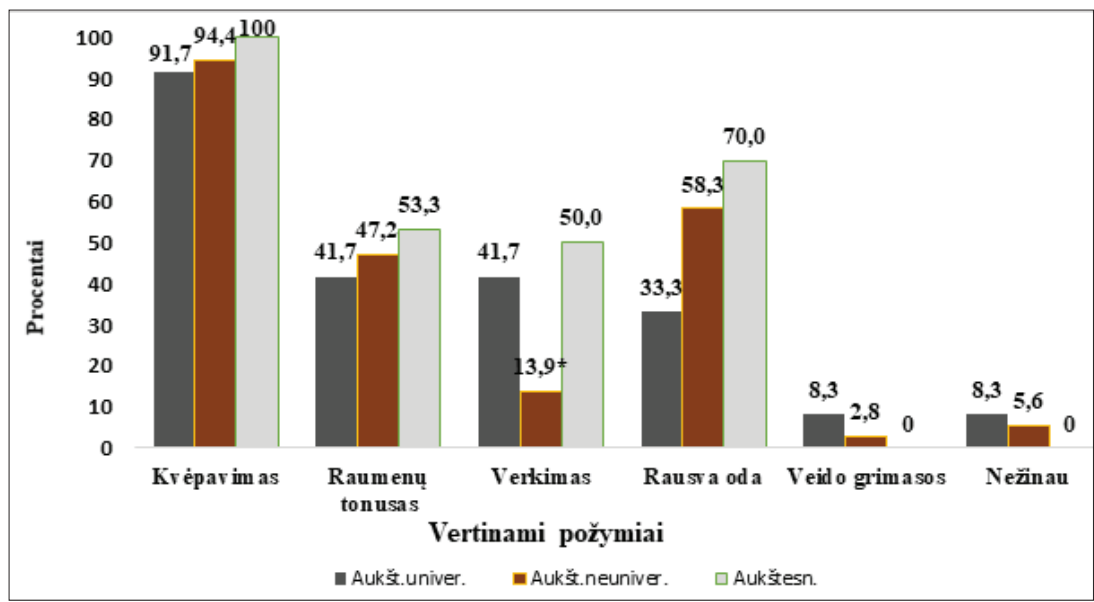

1 pav. Slaugytojų žinios apie požymius, rodančius naujagimio gaivinimo poreikị $p<0,05$, lyginant su aukštuoju universitetiniu ir aukštesniuoju išsimokslinimu

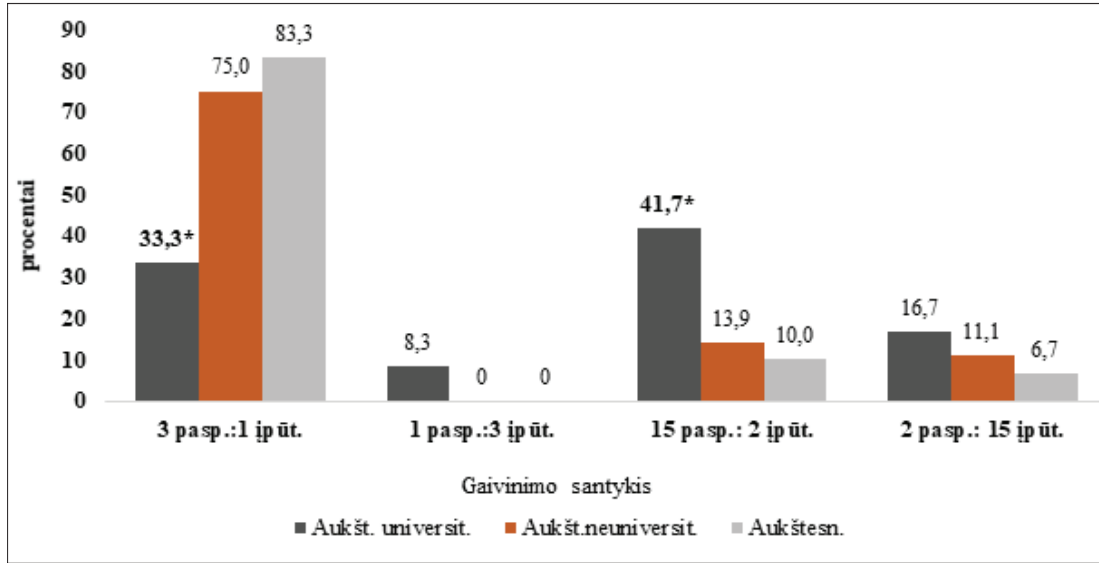

2 pav. Slaugytojų žinios apie naujagimio gaivinimo paspaudimų ir ịpūtimų santykị $p<0.05$, lyginant su aukštuoju neuniversitetiniu ir aukštesniuoju išsimokslinimu versitetini $(91,7$ proc., $\mathrm{n}=11)$ išsimokslinimą, norèdami nustatyti naujagimio gaivinimo poreikį, vertintų, ar naujagimis kvėpuoja (1 pav.). Norédami nustatyti naujagimio gaivinimo poreiki, apie pusè $(50,0$ proc., $n=15)$ respondentų, turinčių aukštesniji išsimokslinimą, kiek mažiau nei pusè turinčiu aukštaji universitetini ( 47,2 proc., $n=5)$ išsimokslinimą, nurode, kad vertintų, ar naujagimis verkia, bet tai vertintų reikšmingai mažiau respondentų, turinčių aukštajj neuniversitetinị $(13,9$ proc., $\mathrm{n}=5)$ išsimokslinimą $(p<0,05)$. Kiek daugiau nei puse $(53,3$ proc., $\mathrm{n}=16)$ tyrimo dalyvių, turinčių aukštesnijji išsimokslinimą, mažiau nei pusè, turinčių aukštaji neuniversitetinị ( 47,2 proc., $n=17$ ) ir aukštaji universitetinị ( 41,7 proc., $n=5)$ išsimokslinimą, nurodè, kad nustatydami naujagimio gaivinimo poreiki, vertintų naujagimio raumenų tonusą. Labai maža dalis (aukštasis neuniversitetinis išsimokslinimas $-8,3$ proc., $\mathrm{n}=1$; aukštasis neuniversitetinis išsimokslinimas $-5,6$ proc., $\mathrm{n}=1$ ) tyrime dalyvavusių slaugytojų nurodè, kad nežino, kokius požymius reikètų vertinti, nustatant naujagimio gaivinimo poreikị (1 pav.).

Tyrimo rezultatai atskleidè, kad pirmuosius naujagimio gaivinimo veiksmus ne ilgiau kaip 30 sek. atliktų daugiau nei pusė tyrimo dalyvių, turinčių aukštesniji $(67,7$ proc., $n=20)$, aukštaji neuniversitetini (66,7 proc., $\mathrm{n}=24)$ ir mažiau nei pusè (41,7 proc., $\mathrm{n}=8$ ) aukštaji universitetini išsimokslinimą ( $p>0,05)$. Mažiau nei trečdalis $(30,0$ proc., $n=9)$ respondentų, turinčių aukštesniji išsimokslinimą, ketvirtadalis $(25,0$ proc., $n=3)$ - aukštaji universitetini, daugiau nei dešimtadalis $(13,9$ proc., $n=5)$ - turinčiu aukštaji neuniversitetinį išsimokslinimą nurodè, kad pirmieji naujagimio gaivinimo veiksmai turetų būti atlikti ne ilgiau kaip per 60 sek. Apie penktadalis (19,4 proc., $\mathrm{n}=7$ ) respondentų, turinčių aukštaji neuniversitetinị išsimokslinimą, mažiau nei dešimtadalis ( 8,3 proc., $n=1)$ - aukštaji 
universitetini, labai maža dalis (3,3 proc., $\mathrm{n}=1$ ) - turinčių aukštesnijji išsimokslinimą nurodè, kad pirmieji naujagimio gaivinimo veiksmai turètų būti atliekami ne ilgiau kaip 15 sekundžių.

Analizuojant tyrimo rezultatus, atsiŽvelgiant respondentų išsimokslinimą, nustatyta, kad didesnè dalis respondentu, turinčių aukštesniji ( 86,7 proc., $n=26$ ), aukštaji neuniversitetinį $(75,0$ proc., $n=27)$ ir aukštajj universitetini ( 75,0 proc., $n=9$ ) išsimokslinimą, nurodè, kad atliktu 20-30 įpūtimų. Kiek daugiau nei dešimtadalis (13,9 proc., n=5) slaugytojų, turinčių aukštaji universitetinị ir apie dešimtadalis $(8,3$ proc., $\mathrm{n}=1$ ) turinčių aukštaji neuniversitetinị išsimokslinimą, nurodè, kad gaivindami naujagimi, per 30 sek. atliktų 10-15 ịpūtimų, tačiau taip nemano nè vienas slaugytojas, turintis aukštesniji išsimokslinimą. Maža dalis (aukštasis universitetinis $-8,3$ proc., $\mathrm{n}=1$; aukštasis neuniversitetinis $-5,6$ proc., $\mathrm{n}=2$; aukštesnysis $-3,3$ proc., $\mathrm{n}=1$ ) respondentų nurode, kad reikètų atlikti 3040 ịpūtimų.

Didžioji dalis slaugytojų, turinčių aukštesnijj (83,3 proc., $n=25)$ ir aukštaji neuniversitetini $(75,0$ proc., $n=27)$ išsimokslinimą, naujagimi gaivintų santykiu 3 krūtinès paspaudimai: 1 ịpūtimas, tačiau tokiu santykiu gaivintų reikšmingai mažesnè dalis respondentų, turinčių aukštaji universitetini $(33,3$ proc., $n=4)$ išsimokslinimą $(\mathrm{p}<0,05)$. Mažiau nei pusè $(41,7$ proc., $n=5$ ) slaugytojų, turinčių aukštaji universitetinį išsimokslinimą, teigè, kad 2 parų naujagimi gaivintų santykiu 15 paspaudimų: 2 ịpūtimai, tačiau tokiu santykiu naujagimi gaivintų statistiškai reikšmingai mažiau slaugytojų, turinčių aukštajį neuniversitetini $(13,9$ proc., $n=5)$ ir aukštesniji išsimokslinimą $(10,0$ proc., $n=3)(p<0,05)$. Apie penktadalis slaugytojų, turinčių aukštajị universitetini ( 16,7 proc.,n=2), apie dešimtadalis slaugytojų, turinčių aukštajį neuniversitetini ( 11,1 proc., $\mathrm{n}=4)$ ir aukštesniji (6,7 proc., $n=2)$ išsimokslinimą, mano, kad 2 parų naujagimi reikètų gaivinti santykiu 2 paspaudimai: 15 ịpūtimų ( 2 pav.).

Tyrimo metu nustatyta, kad didžioji da-

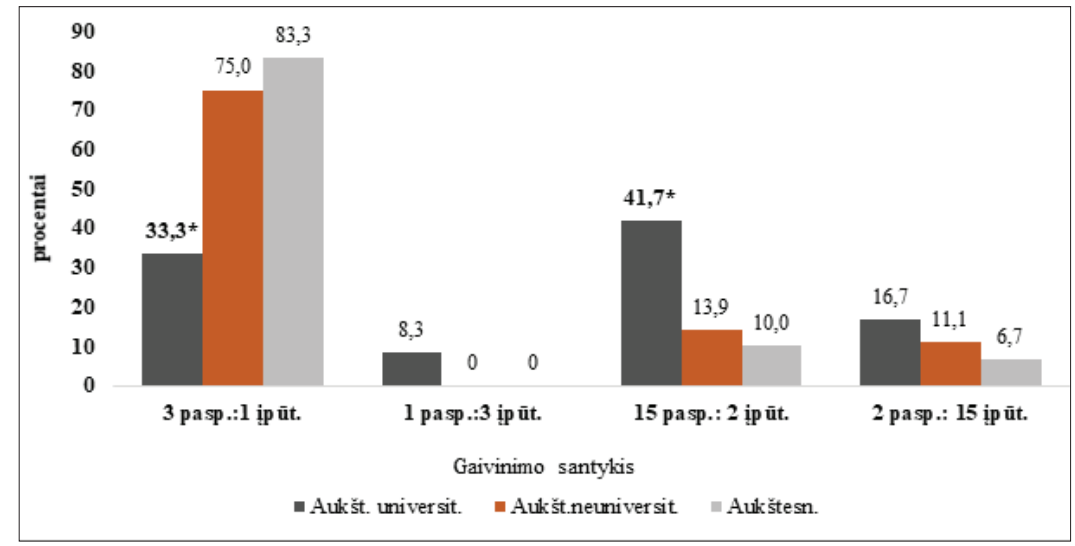

3 pav. Slaugytojų žinios apie naujagimio krūtinès ląstos paspaudimų metodus $p<0,05$, lyginant su aukštuoju neuniversitetiniu ir aukštesniuoju išsimokslinimu

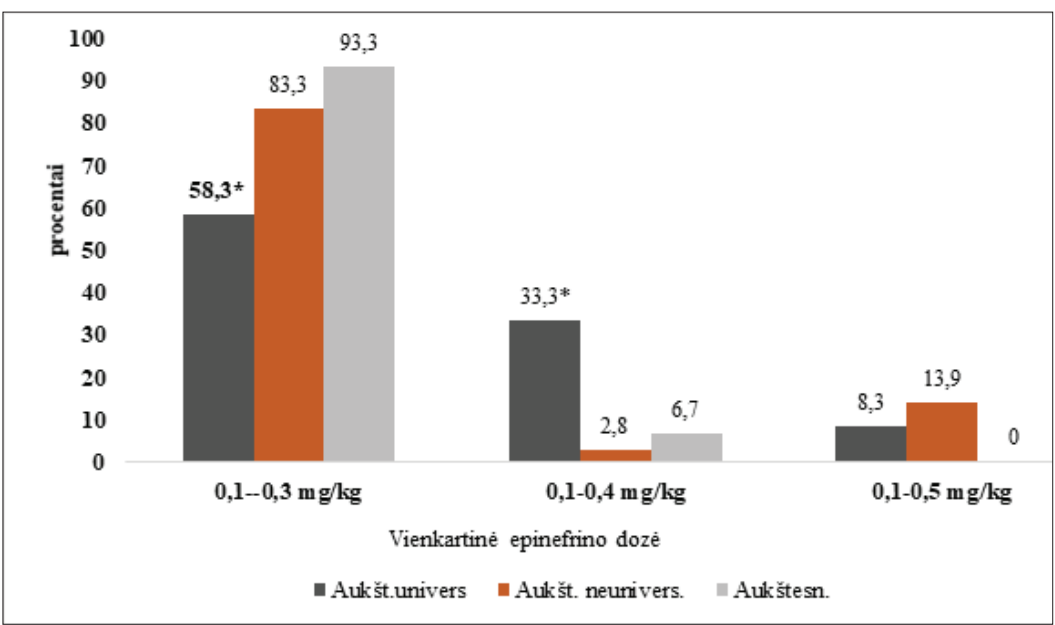

4 pav. Slaugytojų žinios apie naujagimio gaivinimo metu vieną kartą sušvirkščiamą epinefrino dozę

$p<0.05$, lyginant su aukštuoju neuniversitetiniu ir aukštesniuoju išsimokslinimu

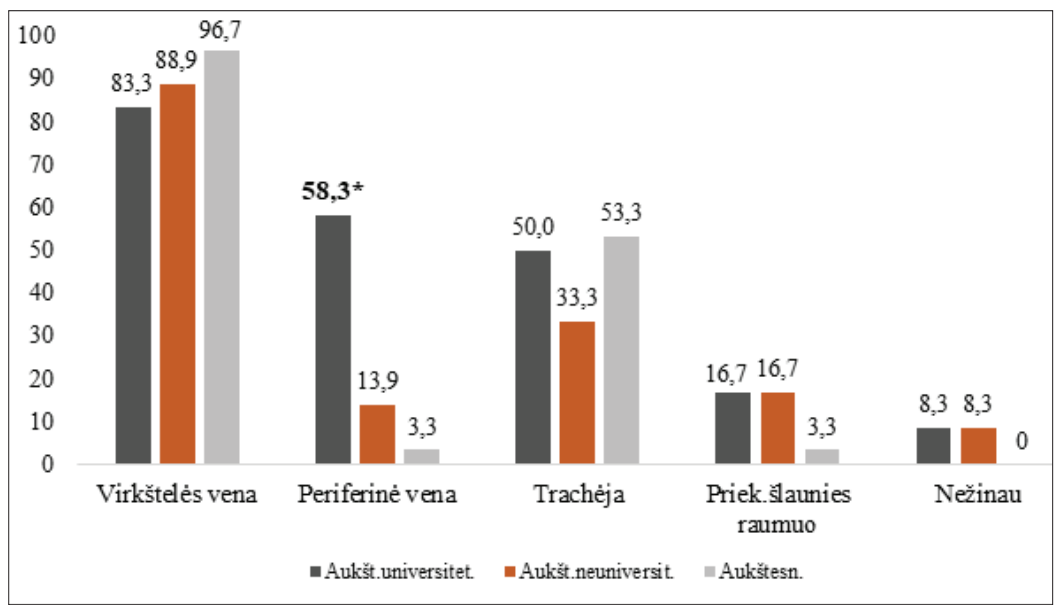

5 pav. Slaugytojų žinios apie epinefrino injekcijos vietą naujagimio gaivinimo metu $p<0,05$, lyginant su aukštuoju neuniversitetiniu ir aukštesniuoju išsimokslinimu. 
lis tyrimo dalyvių, turinčių aukštesniji ( 93,3 proc., $\mathrm{n}=28)$, aukštaji neuniversitetini ( 91,7 proc., $n=33)$ ir aukštaji universitetinį ( 83,3 proc., $n=10)$ išsimokslinimą, krūtinès ląstos paspaudimus atliktų taikydami dviejų nykščių metodą. Krūtinès ląstos paspaudimus dviem pirštais atliktų daugiau nei pusè $(66,7$ proc.,n=8) slaugytojų, turinčių aukštajji universitetinị išsimokslinimą, apie pusè $(53,3$ proc., $n=16)$ turinčių aukštesnijị išsimokslinimą, tačiau šį krūtinès ląstos paspaudimų metodą naudotų statistiškai mažiau (22,2 proc., $\mathrm{n}=8$ ) slaugytojų, turinčių aukštajį neuniversitetinị išsimokslinimą $(p<0,05)$. Kad krūtinès ląstos paspaudimus atliktų apatiniame krūtinkaulio trečdalyje, nurodè ketvirtadalis $(25,0$ proc., $n=3$ ) respondentų, turinčių aukštaji universitetinị išsimokslinimą, kiek daugiau nei dešimtadalis $(13,9$ proc., $n=5)$ turinčių aukštajį neuniversitetinị išsimokslinimą, tačiau nė vienas respondentas, turintis aukštesnịji išsimokslinimą, naujagimiui apatiniame krūtinkaulio trečdalyje paspaudimu neatliktų $(\mathrm{p}<0,05)(3$ pav. $)$.

Didžioji dalis tyrimo dalyvių, turinčių aukštesnijj (93,3 proc., $\mathrm{n}=28)$ ir aukštaji neuniversitetini $(83,3$ proc., $\mathrm{n}=30)$, gaivindami naujagimị, švirkštų vienkartinę epinefrino dozę $0,1-0,3 \mathrm{ml} / \mathrm{kg}$. Tokią dozę švirkštų tik kiek daugiau nei pusė $(58,3$ proc., $n=7)$ respondentu, turinčių aukštaji universitetini išsimokslinimą $(\mathrm{p}<0,05)$. Apie trečdalis $(33,3$ proc., $\mathrm{n}=4)$ slaugytojų, turinčių aukštaji universitetinį išsimokslinimą ir labai maža dalis turinčiu aukštesniji $(6,7$ proc., $n=2)$ ir aukštajji neuniversitetini ( 2,8 proc., $n=1)$ išsimokslinimą nurodè, kad, gaivindami naujagimį, vieną kartą švirkštų epinefrino dozę $0,1-0,4 \mathrm{ml} / \mathrm{kg}(\mathrm{p}<0,05)$ (4 pav.).

Tyrimo rezultatų analizè parodè, kad didžioji dalis tyrime dalyvavusių slaugytojų (aukštesnysis $-96,7$ proc., $\mathrm{n}=29$, aukštasis neuniversitetinis $-88,9$ proc., $\mathrm{n}=32$, aukštasis universitetinis $-83,3$ proc., $n=10$ ) teige, jog gaivinant naujagimį, epinefriną švirkštų i virkštelès veną. Daugiau nei puse $(58,3$ proc., $n=7)$ tyrimo dalyvių, turinčių aukštaji universitetinị išsimokslinimą, nurodè, kad epinefriną švirkštų i periferinę veną, tačiau taip nurodè reikšmingai mažiau slaugytojų, turinčių aukštajị neuniversitetinį $(13,9$ proc., $n=5)$ ir aukštesnijj $(3,3$ proc., $n=1)$ išsimokslinimą $(\mathrm{p}<0,05)$. Kiek daugiau nei pusè (53,3 proc., $\mathrm{n}=16$ ) slaugytojų, turinčiuc aukštesnijji, pusė (50,0 proc., $\mathrm{n}=7)$ - aukštaji universitetini ir apie trečdalis $(33,3$ proc., $n=12)$ turinčių aukštaji neuniversitetinị išsimokslinimą, epinefriną švirkštų i trachèją per endotrachèjini vamzdelị. Kiek mažiau nei penktadalis slaugytojų, turinčiu aukštaji universitetinį ( 16,7 proc., $n=2)$ ir aukštaji neuniversitetinị ( 16,7 proc., $n=6)$ išsimokslinimą ir labai maža dalis $(3,3$ proc., $\mathrm{n}=1)$ turinčių aukštesniji išsimokslinimą, mano, kad gaivinant naujagimį, epinefriną švirkštų ị vidurinio šlaunies trečdalio šoninio paviršiaus raumenị (5 pav.).

\section{Išvados}

1. Didžioji dalis slaugytojų, turinčių aukštesnijj ir aukštajį neuniversitetinį išsimokslinimą, žinojo pirmujų naujagimio gaivinimo veiksmų trukmę, ịpūtimų skaičių per 30 sek., paspaudimų ir ịpūtimų santykị, vienkartinę epinefrino dozę. Didžioji dalis turinčių aukštajị universitetinį išsimokslinimą žinojo ịpūtimų skaičių per 30 sek., krūtinès ląstos paspaudimų metodą.

2. Nedidelè dalis slaugytojų, turinčių aukštajị universitetinį ir aukštaji neuniversitetinị išsimokslinimą, nežinojo tikslaus naujagimio paspaudimų ir ịpūtimų santykio, naujagimio gaivinimo metu švirkščiamo epinefrino dozès ir injekcijos vietos.

\section{Literatūra}

1. United Nations, Department of Economic and Social Affairs, Population Division (2019). Population Facts No. 2019/5, December 2019: Potential Impact of Later Childbearing on Future Population. https://population.un.org/wpp/Publications/

2. Plecher H. Statista: Number of live births in the EU in 2018. https://www.statista.com/statistics/253401/number-of-livebirths-in-the-eu/.

3. Oficialios statistikos portalas. Lietuvos gyventojai (2020 leidimas). Gimstamumas. https://osp.stat.gov.lt/lietuvos-gyventojai-2020/gimstamumas

4. Oficialios statistikos portalas. Lietuvos gyventojai (2020 leidimas). Kūdikių mirtingumas. https://osp.stat.gov.lt/lietuvosgyventojai-2020/mirtingumas/kudikiu-mirtingumas

5. Gaidelytẻ R., Garbuvienè M. Kūdikių mirtingumas 2016 m. Higienos instituto Sveikatos informacijos centras. Vilnius, 2017.

6. Wyckoff MH, Aziz K, Escobedo MB, Kapadia VS, Kattwinkel J, et al. Part 13: Neonatal Resuscitation: 2015 American Heart Association Guidelines Update for Cardiopulmonary Resuscitation and Emergency Cardiovascular Care. Circulation 2015; 132(suppl 2):S543-S560.

https://doi.org/10.1161/CIR.0000000000000267

7. Wyllie J, Bruinenberg J, Roehr CC, Rüdiger M, Trevisanuto D, Urlesberger B. European Resuscitation Council Guidelines for Resuscitation 2015: Section 7. Resuscitation and support of transition of babies at birth. Resuscitation 2015; (95):249-263. https://doi.org/10.1016/j.resuscitation.2015.07.029

8. Abraitis, V., Aldakauskienè, I., Arlauskienè, A., Bagušyte,, L., Bartusevičienè, E., Bartusevičius, A. ir kt. Perinatologijos praktikos vadovas. Pirmoji knyga. Normalus néštumas ir gimdymas. Antroji knyga. Skubioji akušerinè pagalba. Trečioji knyga. Něštumo patologija ir gretutinès ligos. Ketvirtoji knyga. Skubioji neonatologinè pagalba. Penktoji knyga. Naujagimių ligos ir patologinès būklès. Vilnius, UAB Tarptautinè skubiosios medicinos akademija, 2016: 488.

9. LR sveikatos apsaugos ministro $2011 \mathrm{~m}$. rugpjūčio $31 \mathrm{~d}$. isakymas Nr. V-822 Dẻl gaivinimo standartų patvirtinimo. Valstybės žinios, 2011-09-06, Nr. 110-5214. 
https://e-seimas.lrs.lt/portal/legalAct/lt/TAD/TAIS.405743

10. LR sveikatos apsaugos ministro $2018 \mathrm{~m}$. rugsejjo $12 \mathrm{~d}$. ịsakymas Nr. 1008 Dèl Lietuvos Respublikos sveikatos apsaugos ministro 2011 m. rugpjūčio 31 d. ịsakymo Nr. V-822, „Dèl gaivinimo standartų patvirtinimo" pakeitimo. TAR, 2018-0914, Nr. 14535.

https://e-seimas.lrs.lt/portal/legalAct/lt/TAD/aeff0d80b80811e8a a33fe8f0fea665f

11. Frazier MD, Werthammer J. Post-resuscitation complications in term neonates. Journal of Perinatology 2007; 27(2), 82-84. https://doi.org/10.1038/sj.jp.7211644

12. Perlman JM, Wyllie J, Kattwinkel J, Atkins DL, Chameides L, Goldsmith JP, Guinsburg R, Hazinski MF, Morley C, Richmond S, Simon WM, Singhal N, Szyld E, Tamura M, Velaphi S. Neonatal Resuscitation Chapter Collaborators. Part 11: Neonatal resuscitation: 2010 International Consensus on Cardiopulmonary Resuscitation and Emergency Cardiovascular Care Science With Treatment Recommendations. Circulation 2010;122(16 Suppl 2):S516-38.

https://doi.org/10.1542/peds.2010-2972B

13. Fernandes CJ. Neonatal resuscitation in the delivery room. UpToDate 2020. https:/www.uptodate.com/contents/neonatalresuscitation-in-the-delivery-room.

14. Gonçalves RL, Tsuzuki LM, Carvalho MGS. Endotracheal suctioning in intubated newborns: an integrative literature review. Revista Brasileira de Terapia Intensiva 2015; 27(3), 284-292. https://doi.org/10.5935/0103-507X.20150048

15. LR sveikatos apsaugos ministro $2019 \mathrm{~m}$. liepos $12 \mathrm{~d}$. įsakymas Nr. 828 Dèl Lietuvos Respublikos sveikatos apsaugos ministro 2011 m. birželio 8 d. įsakymo Nr. V-591 „Dèl Lietuvos medicinos normos MN 28:2011 „Bendrosios praktikos slaugytojas. Teisès, pareigos, kompetencija ir atsakomybe்" patvirtinimo" pakeitimo. TAR, 2019-07-15, Nr. 11623.

https://e-seimas.lrs.lt/portal/legalAct/1t/TAD/024dd4c1a6d911e9a ab6d8dd69c6da66?jfwid=-7zs1t4akb

16. Gauro P, Saha A, Adhikari B. Knowledge and Skill of Newborn Resuscitation among Nurses Working in Maternity Ward. International Journal of Health Sciences and Research 2018; 8(2):149-154. https://www.ijhsr.org/IJHSR_Vol.8_Issue.2_ Feb2018/19.pdf.

17. Szarpak $€$. Knowledge of newborn resuscitation among emergency medical personnel. Anaesthesiology Intensive Therapy 2013; 45(2):73-76.

https://doi.org/10.5603/AIT.2013.0016
18. Kester-Greene N, Lee JS. Preparedness of urban, general emergency department staff for neonatal resuscitation in a Canadian setting. Canadian Journal of Emergency Medicine 2014; 16(5), 414-420.

https://doi.org/10.2310/8000.2013.131156

\section{NURSES KNOWLEDGE OF NEONATAL RESUSCITATION ACCORDING TO EDUCATION S. Kostyliovienė, T. Mažeikaitė, M. Krauzaitè, D. Grinkevičiūtė, A.Vaškelytė}

Keywords: newborn recuscitation, nurse knowledge, nurse educations.

Summary

According to the World Health Organization (WHO), 2.5 million newborns died worldwide in the first month of life in 2018. About 7,000 newborns die each day. The causes of death of newborns can be varied, but most often they die from congenital malformations, infections, diseases of the perinatal period, diseases of the respiratory or circulatory system, sudden infant death syndrome (SIDS) or birth trauma. Neonatal resuscitation guidelines differ from those intended for an adult or child not only in the ratio of chest compressions and rescue breaths, but also in the very first actions of resuscitation. It is claimed that about $61 \%$ of newborns experience various complications during resuscitation. Healthcare professionals providing emergency care should be aware of the standard of resuscitation of the newborn and be able to perform the newborn's resuscitation qualitatively. This article reveals the knowledge of nurses about resuscitation of newborns, taking into account their education. The quantitative method- the survey was used to collect the data. Seventy-eight nurses providing emergency and emergency care to newborns were interviewed. The results show that a higher proportion of nurses with higher and higher non-university education know the duration of the first resuscitation actions of the newborn, the number of breaths in 30 seconds, the ratio of chest compressions and breaths, the single dose of epinephrine. A larger proportion of nurses with higher university education knew the number of breaths in 30 seconds, a methodology of chest compressions. A small percentage of nurses with higher university and higher non-university education are unaware of the dose of epinephrine injected during resuscitation of the newborn and the injection site.

Correspondence to: silva.kostylioviene@go.kauko.lt

Gauta 2021-10-20 